\title{
7. TRAINING OF ARTISTIC SKILLS OF THE MUSIC TEACHER
}

\author{
Margarita Tetelea ${ }^{270}$
}

\begin{abstract}
In this article, concepts such as "creativity" and "artistic creativity", based on the ideas of a number of famous scholars, are dealt with. The concept of "creativity" is defined according to the aspiration of an artistic person to self-expression. Speaking about the structure and the components of the creative process, we have identified the factors that enhance the development of the creative abilities of the students from the pedagogic-artistic specialties in the process of designing the didactic-artistic approach. It is also reflected in the diversity of these factors: psychological, pedagogical, didactic, artistic. In conclusion, the emphasis is on the fact that self-expression in artistic creativity is the individual's need, and need is classified as aesthetic.
\end{abstract}

Key words: artistic creativity, self-expression, creative process, artistic personality, skills

Creative movement is a sign of being perfect

Berdyaev N.A.

\section{Introduction}

In the modern didactics, the development of students' artistic and creative skills is one of the most important issues of education and of training the professional competences of the future specialist. Creativity as an activity is specific and embodies the universal potential of the human being. Here, unlike the game, there is a purpose, a product, but which is not rigidly and univocally determined. In the certainty of the final product, creative activity is more or less characteristic through something natural. For a creative personality, it is known that the creative process is often more important, more attractive, for the creativity process than for the final product. The relevance of this research is owed to the fact that the creative approach of the artistic activity in itself is based on concrete impressions, as a result of inspiration, and on the newly emerged ideas, beneficial for the subsequent training and development of artistic personality.

\section{Discussions}

The ability to identify and isolate, the ability to be alone and another, it designed in the creative process as a mechanism of identification with the object of self-knowledge, of the subject of creativity and of the object in itself. N.A. Berdyaev refers to it, as being a person's love and its scientific nature. Namely, such an identification, the personal penetration of the "interior" of the object of creativity, the merger of the object and subject ("the short-circuit between then", the emergence of one whole) is at the foundation of the main mechanism of

\footnotetext{
270 Associate Professor PhD., „Alecu Russo” State University from Bălţi, Republic of Moldavia, email: mtetelea@yahoo.com
} 
creativity: revelation-understanding-discovery. As it is known, this mechanism is essentially carried out at the level of the unconscious, intuitively, little subjected to reflextion, self-observation, remains hidden for its direct detection. In this context, the personal approach of creativity, taking the latter in consideration in the context of design in the process of creativity of skills and personal mechanisms is very productive [1].

Referring to creativity, scientists in various fields of knowledge are identical in ideas regarding the defining of the content of this process. Russian psychologist L.S. Vygotsky calls a human creative activity "the activity that contributes to the creation of a new work of art" [8]. He does not emphasize whether it is created by the creative activity of a thing in the exterior world or by the construction of the mind or feelings that live and are found only inside the person himself/herself. L. S. Vygotsky divides human activity into two main types of action. The first one is the memory, reproduction, recreation (in this case nothing new is created, the basis of the activityis a repetition more or less exact of what had already existed). The second one is creative, combined, which targets the creation of new actions and images (in this case, new provisions, new behaviours are created from elements of previous experience) [8].L.S .Vygotsky concludes that the creation activity of a person makes him/her a creature confronting with the future, creating and modifying the present [8].

The Russian scholar A. N. Luc studied in various works the issue of creativity. In one of them, revealing the essence of the processes that are at the foundation of creation, he remarks that the creative action and the common solution have the same psychological structure [3]. In this context he divides the creative process in several stages:

a) accumulation of knowledge and skills necessary for understanding and the clear formulation of the task;

b) search of additional information;

c) search of a solution at the level of the unconscious with the external escape from the problem;

d) revelation or understanding (exterior understanding seems to be a logical discontinuity, a leap in thinking, obtaining a result which does not clearly results from the premises);

e) assessing or checking the creative solution found [4].

According to American psychologist E.Rossman the process of scientific creativity is divided into seven stages:

1. becoming aware of the need to solve a creative problem;

2. analysis of creative problems;

3. studying the information necessary for the purpose of solving the problem;

4. analysis of the solutions previously proposed of such a creative task;

5. typical analysis of these decisions;

6. birth of a new idea;

7 .experimental assessment of a new solution to a creative problem [5]. 
The approach of E. Rossman in drafting stages of creativity is, in our opinion, complete and enforceable to any creative process, including in the methodical-artistic activities of the future music teacher. Arguing the structure of the creative process, it is impossible to ignore the factors influencing the activation of creative skills of students, future music teachers, in the process of didactic-artistic design. There are many factors: psychological, pedagogic, didactic, creative, artistic. Psychological factors include thus characteristics of the flow of mental processes such as imagination and fantasy, which affect the process of design. L.S. Vygotsky spoke about imagination, as a foundation for the entire creative activity, which is manifested in all aspects of cultural life, making artistic, scientific and technical creativity possible [8].

Endeavouring to discover the reasons that had inspired someone in the work of French scholar T. Ribot in 1901, in his book "Creative Imagination" he wrote that "the capacity to create is conditioned by two main reasons for a person. The first of these, has the character of a motor incentive, it is reduced to the action of his/her needs, aspirations and desires. The second is the possibility of the spontaneous awakening of images grouped into new combinations" [6]. Each need, desire or calling can serve as an impulse for creativity, but needs and desires cannot create anything alone, another condition is also necessary - the spontaneous resurrection of images. Spontaneous Resurrection T. Ribot calls what happens suddenly, without being explicitly caused. The reasons for these exist, but their action is covered in a hidden form of artistic thinking.

The need for creativity is closely connected with the capacity of imagination, which, in turn, emerges if we start from the reflections of T. Ribot, from the needs, aspirations and desires of a person [6]. Modern researchers have expressed this idea in a slightly different manner. For this purpose, it is very interesting to study the circumstances affecting the success of I.M. Roset [7]. Here Argentinean psychologist I.M .Roset writes that besides the need for selfexpression, there is also a need for discontent, with any aspect of real activities, serving as an important reason for fantasy. Dissatisfaction appears based on the constant efforts of adolescence, simplicity, order. The researcher concludes that satisfaction and the desire for self-expression can be internal stimulents of the creative activity of the same person [7]. I.M. Roset considers another reason encouraging creativity - the desire to create objects and images that are not similar to the effective in this situation. The tendency to oppose, together with the tendency to create by analogy, are the main reasons of creativity, the latter involuntarily manifesting in human intelligence [7].

\section{Results}

Thus, creativity is a dynamic process, depending not only on the natural dispositions of a person. Creativity develops and increases, as the sphere of objective world transformed by the human being, the sphere of its titles and skills extends. The role of creativity in musical art is of a great importance, so that one 
of the main tasks of the artistic development of the individual is building its creative skills. That is why we should state that remarkable artistis-teachers have often solved the task of the creative growth of students empirically. That is why we should state that remarkable artists-teachers have often solved the task of the creative development of students empirically. The ones who tried to scientifically and theoretically found the work experience relied on a series of educational and creative tasks.

Moldovan scholar I. Gagim, in his psychology treaty states: " I have stressed the complexity of the human psyche in order to prove, on the one hand, under what conditions the psychologist is in the case of treating (explanation, definition and usage for various purposes) of what is essential for the human being, of what constitutes its "essence", on the other hand, under what conditions is the musician (creator of art), called to render in his/her work nothing else but this inner world with its entire register of contradictions"(2)

The studies carried out by psychologists and physiologists have proven that creativity, perception, study and practical work are inseparably connected. The assimilation of knowledge, the acquisition of technical competences and the development of creative skills cannot be artificially isolated. Development should take place simultaneously and simultaneously with the acquisition of scientific knowledge and practical skills, mutually complementary. The accumulation of creative experience should stimulate the study and assimilation of interpretativeartistic competences.

\section{Conclusions}

From the above-mentioned one can conclude that the role of creativity in building the artistic competences of the teacher is high, as self-expression in artistic creativity is the individual's necessity, but the necessity, belonging to the aesthetic category. The term of "necessity" means the need, the desire to create and, based on the definitions of various authors, emerges due to reasons of "selfappreciation", discontent and the desire to act in contradiction with the generally accepted existence. It is clear that all these reasons are not common, but interdependent. The competence of self-expression of the teacher in the artistic creativity is not possible without the capacity of creative imagination, which is closely connected to the reasons listed above. Thus, the task of building the teacher's competences in modern methodology is not only of offering the students a certain knowledge, but also of developing artistic and creative skills connected to the independent search of new manners of activity, the skill to raise issues and to find creative means to solve them. 


\section{References}

1. Berdeaev N.A. Autocunoasterea (o experiență filosofică de autocunoaștere) Moscova,1972, p.223

2. Gagim. I. Dimensiunea psihologică a muzicii, Editura Timpul, Iași, p. 92

3. Luk A.N. Găndirea și creativitatea - Moscova, 1976, p.129

4. Luk A.N. Psihologia creației - Moscova, 1978, p.119

5. Rossman E. Metode grafice în diagnosticul psihologic-Moscova, 1983, p. 154

6. Ribot T. Essai sur l'imagination créatrive -19

7. Rozet I.M. Psicologia de La Fantasia. - Madrid, 1981, p. 134-137

8. Vygodski L.S. Psihologia artei. - Moscova, 1965, p. 33-66. 